\title{
PERBEDAAN PENGARUH SENAM YOGA DAN SENAM TAI CHI TERHADAP PENURUNAN NYERI PADA OSTEOARTRITIS LUTUT
}

\author{
Maulida Rohmah Fauziah \\ Politeknik Kesehatan Surakarta \\ Email: maulida.fauziah@ymail.com
}

\begin{abstract}
The enhancement of elderly rate in Indonesia will increase risk of degenerative diseases prevalence such as knee osteoarthritis. Pain is the biggest issue for OA patients that lead to joint immobility and quality of life. Based on that issue, we need mind and body approach that will decrease knee OA pain such as Yoga and Tai Chi.The goals are knowing the effect of Yoga on knee OA pain, the effect of Tai Chi on knee OA pain, the difference effect of Yoga and Tai Chi on knee OA pain, and the most effective mind and body exercise on knee OA pain. Sixteen elderly women at Posyandu Ngudi Kasarasan, Malangjiwan, Colomadu, Karanganyar, Jawa Tengah from age 50 to 74 year old. This research uses two group pre and post test design. Sixteen subjects have been divided into two groups. The fisrt group $(n=8)$ receive Yoga intervention and the second group $(n=8)$ receive Tai Chi intervention. These groups receive intervention 3 times a week for 12 weeks or 3 months. The researcher use Woman Ontario McMaster University pain scale Likert version (WOMAC pain scale likert version) to scale the pain intensity. The research result is analyzed by the statistical analysis are performed in descriptive and non parametric test. Based on the statistic result, the knee pain intensity decrease significantly in Yoga group, which is obtained significance value or $p=0.011$ ( $p<0.05)$. The knee pain intensity also decrease significantly in Tai Chi group with significance value or $p=0.011$ ( $p<0.05$ ). The result of difference test between Yoga and Tai Chi group obtaining significance value or $p=0.220(p>0.05)$ which means there is no significant difference between Yoga and Tai Chi group on knee OA pain. This research shows that Yoga and Tai Chi have the same effect on reducing knee OA pain. Therefore, the elderly at Posyandu Lansia Ngudi Kasarasan should perform Yoga or Tai Chi to reduce knee pain due to knee OA and achieve better quality of life.
\end{abstract}

Keywords: Knee osteoarthritis; Tai Chi; Yoga; pain.

\begin{abstract}
Abstrak
Peningkatan jumlah lansia di Indonesia meningkatkan pula risiko peningkatan penyakit degeneratif seperti osteoarthritis lutut. Problematik yang paling dikeluhkan oleh pasien osteoarthritis lutut adalah nyeri yang akan menurunkan mobilitas sendi dan kualitas hidup. Berdasarkan masalah tersebut, diperlukan senam yang dapat menurunkan nyeri OA lutut melalui pendekatan mind and body seperti senam Yoga dan Tai Chi. Penelitian ini bertujuan untuk mengetahui pengaruh senam Yoga terhadap penurunan nyeri pada osteoartritis lutut, pengaruh senam Tai Chi terhadap penurunan nyeri pada osteoartritis lutut, perbedaan pengaruh antara senam Yoga dan senam Tai Chi terhadap penurunan nyeri pada
\end{abstract}


osteoartritis lutut, metode yang lebih efektif antara senam Yoga dan senam Tai Chi terhadap penurunan nyeri pada osteoartritis lutut. 16 lansia wanita di posyandu Ngudi Kasarasan Desa Malangjiwan, Colomadu, Karanganyar, Jawa Tengah dengan usia antara 50-74 tahun. Penelitian ini menggunakan desain two groups pre and post test. Subyek sebanyak 16 lansia wanita dibagi menjadi 2 kelompok menggunakan undian. Kelompok I mendapatkan perlakuan senam Yoga dan kelompok II mendapatkan perlakuan senam Tai Chi. Perlakuan dilakukan seminggu 3 kali, selama 12 minggu. Pengukuran nyeri menggunakan Woman Ontario Measure versi skala likert (WOMAC PAIN SCALE). Analisis dilakukan secara deskriptif dan statistic menggunakan uji hipotesis non parametrik. Berdasarkan hasil statistik, terjadi penurunan nyeri yang signifikan pada kelompok I (Yoga) dengan nilai signifikansi $\mathrm{p}=0.011(\mathrm{p}<0.05)$ dan penurunan nyeri yang signifikan pada kelompok II (Tai Chi) dengan nilai signifikansi $\mathrm{p}=0.011(\mathrm{p}<0.05)$. Uji beda antara kelompok I dan II, diperoleh nilai signifikansi $\mathrm{p}=0.220(\mathrm{p}>0.05)$ yang berarti tidak terdapat perbedaan yang signifikan antara senam Yoga dan senam Tai Chi dalam menurunkan nyeri OA lutut. Penelitian ini menunjukkan bahwa senam Yoga dan senam Tai Chi sama-sama dapat menurunkan nyeri OA lutut. Maka, disarankan kepada posyandu lansia Ngudi Kasarasan untuk melakukan senam Tai Chi maupun Yoga untuk mengurangi nyeri sehingga tercapai kualitas hidup yang lebih baik bagi lansia.

Kata kunci : Osteoarthritis lutut; Tai Chi; Yoga; nyeri.

\section{Pendahuluan}

Penduduk Indonesia mengalami peningkatan derajat kesehatan dan kesejahteraan yang berpengaruh pada peningkatan Usia Harapan Hidup (UHH) dan populasi lanjut usia (lansia). Status gizi lansia dimulai sejak awal kehidupan, yaitu mulai dari sejak periode kehamilan. Pertumbuhan janin yang optimal dilanjutkan dengan pemberian ASI eksklusif dan kecukupan gizi pada masa bayi dan balita menentukan kesehatan pada masa selanjutnya, dimana intensi dan peran ibu dalam memberikan gizi berdampak terhadap status gizi balita, dan selanjutnya secara berkesinambungan menentukan status gizi dan kesehatan pada periode selanjutnya (Komalasari, Permatasari, \& Supriyatna, 2020). Berdasarkan laporan Perserikatan Bangsa-Bangsa (2011), pada tahun 2000-2005 UHH adalah 66,4 tahun dengan persentase populasi lansia tahun 2000 adalah 7,74\% dan angka ini akan meningkat pada tahun 2045-2050 yang diperkirakan UHH menjadi 77,6 tahun dengan persentase populasi lansia tahun 2045 adalah 28,68\%, begitu pula dengan laporan Badan Pusat Statistik (BPS) terjadi peningkatan UHH. Pada tahun 2000, UHH di Indonesia adalah 64,5 tahun dengan persentase populasi lansia adalah 7,18\%. Angka ini meningkat menjadi 69,43 tahun pada tahun 2010 dengan persentase populasi lansia adalah 7,56\% dan pada tahun 2011 menjadi 69,65 tahun dengan persentase populasi lansia adalah 7,58\% (Maharani, 2007).

Adanya peningkatan UHH akan diikuti dengan peningkatan prevalensi penyakit yang berhubungan dengan lansia. Salah satu penyakit yang paling banyak dialami oleh lansia adalah OA lutut.

Gambaran klinis utama dari OA adalah nyeri sendi, krepitasi, kekakuan sendi setelah istirahat, hyperthermia, dan keterbatasan gerak pada lutut yang progresif 
(Schencking, Otto, Deutsch, \& Sandholzer, 2009). Karakteristik utama lainnya OA ditandai dengan adanya degenerasi kartilago sendi dan respon sekunder tulang pembentuk sendi (Ebnezar, Nagarathna, Yogitha, \& Nagendra, 2012). Adanya degenerasi ini, akan mengakibatkan terbentuknya osteophyte dan adanya kontak antar permukaan tulang pembentuk sendi yang menghasilkan nyeri pada sendi tersebut.

Nyeri merupakan gejala utama OA lutut. Semakin berat nyeri yang dirasakan pasien, maka akan semakin rendah tingkat kemampuan aktifitas fungsionalnya. Penurunan kemampuan fungsional ini akan menurunkan pula kualitas hidup pasien (Bennell \& Hinman, 2011).

Menurut the international association for the study of pain (IASP), nyeri adalah suatu pengalaman sensori dan emosional yang tidak menyenangkan, berhubungan dengan kerusakan jaringan secara aktual maupun potensial atau yang didefinisikan dalam istilah tersebut. Nyeri merupakan keluhan utama yang sering dilaporkan pasien dalam setiap kasus OA (Susko \& Fitzgerald, 2013). Nyeri OA dapat berupa nyeri ringan tumpul ringan yang hanya terasa bila pasien melakukan aktivitas berat pada OA lutut derajat 1; nyeri tumpul yang meningkat dan mulai mengganggu aktivitas sehari-hari pada OA lutut derajat 2; dan pada OA derajat 3, nyeri tumpul yang konstan terasa saat melakukan aktivitas ringan hingga pasien tidak dapat melakukan aktivitas di masyarakat (Hawker, Mian, Kendzerska, \& French, 2011).

Penanganan nyeri pada OA lutut merupakan hal yang sangat penting karena kebanyakan keluhan utama pasien adalah nyeri. Berbagai modalitas fisioterapi direkomendasikan untuk mengatasi nyeri. Diantaranya modalitas yang umum diberikan adalah Transcutenous Electrical Nerve Stimulation (TENS) dan latihan penguatan otototot disekitar sendi lutut untuk menangani nyeri pada OA lutut.

Pada masyarakat modern sekarang ini, telah bermunculan berbagai jenis senam yang dapat dijadikan alternatif bagi pasien OA lutut untuk mengurangi nyeri OA lutut yaitu Yoga dan Tai Chi. Yoga sendiri sedang popular dilakukan berbagai kalangan masyarakat termasuk lansia yang berpotensi memiliki masalah lutut. Sedangkan Tai Chi memang sudah menjadi senam yang sering dikaitkan dengan lansia.

Yoga adalah salah satu jenis senam yang memiliki prinsip penyatuan tubuh dan pikiran memalui berbagai postur tubuh. Satu sesi Yoga terdiri dari beberapa bagian yang berbeda yang dilakukan secara berurutan, yaitu (1) postures (asanas of Hatha Yoga), (2) breathing techniques (pranayama) dan (3) mental concentration or meditation (dhyana) (Ebnezar et al., 2012).

Sedangkan Tai Chi adalah bentuk seni bela diri dari kebudayaan Oriental yang mengkombinasikan pernapasan dalam diafragma dan gerakan-gerakan sirkuler yang perlahan dengan postur semi-squat yang membutuhkan gerakan sendi yang tepat, stabil dan seimbang (Chen \& Wong, 2015).

Beberapa penelitian terhadap Yoga dan Tai Chi membuktikan adanya pengaruh yang baik terhadap nyeri pasien OA. Pada penelitian Effectiveness of Yoga Therapy with the Therapeutic Exercises on Walking Pain, Tenderness, Early Morning Stiffness and Disability in Osteoarthritis of the Knee Joint - A Comparative Study oleh (Ebnezar et al., 2012) menunjukkan adanya penurunan nyeri saat berjalan. Tetapi pada penelitian 
(Ghasemi, Golkar, \& Marandi, 2013) berjudul Effects of Hata Yoga on Knee Osteoarthritis, membandingkan kelompok perlakuan Yoga dengan kelompok kontrol, hasilnya tidak terdapat perbedaan pengaruh antara kelompok perlakuan Yoga dan kelompok kontrol.

\section{Metode Penelitian}

Penelitian ini menggunakan desain two groups pre and post test. Subyek sebanyak 16 lansia wanita dibagi menjadi 2 kelompok menggunakan undian. Kelompok I mendapatkan perlakuan senam Yoga dan kelompok II mendapatkan perlakuan senam Tai Chi. Perlakuan dilakukan seminggu 3 kali, selama 12 minggu. Pengukuran nyeri menggunakan Woman Ontario Measure versi skala likert (WOMAC PAIN SCALE). Analisis dilakukan secara deskriptif dan statistic menggunakan uji hipotesis non parametrik.

\section{Hasil dan Pembahasan}

\section{A. Hasil}

\section{Karakteristik Subyek Penelitian}

Pada bulan Januari sampai Maret 2015 telah dilakukan penelitian untuk mengetahui perbedaan pengaruh senam Yoga dengan Tai Chi terhadap penurunan nyeri osteoartritis lutut. Penelitian ini menggunakan rancangan two groups pre test and post test design. Subyek penelitian ini dibagi menjadi 2 kelompok, yaitu kelompok I senam Yoga dan kelompok II senam Tai Chi dengan perlakuan sebanyak 36 kali, seminggu 3 kali selama 3 bulan.

Subyek penelitian ini adalah anggota posyandu lansia di desa Malangjiwan, Karanganyar, Surakarta yang berusia lebih dari 50 tahun yang masuk kriteria inklusi dan eksklusi. Subyek di kelompok I diberikan perlakuan senam Yoga dengan jumlah subyek awal adalah 13 orang, dari total tersebut terdapat 8 orang yang menyelesaikan program dan 5 orang dinyatakan gugur karena subyek tidak mengikuti senam sebanyak 5 kali. Subyek kelompok II diberikan perlakuan berupa senam Tai Chi dengan jumlah subyek adalah 13 orang, dimana sebanyak 8 orang menyelesaikan program, sedangkan 5 orang dinyatakan gugur karena tidak menyelesaikan program. Sehingga jumlah subyek yang dianalisis dari kedua kelompok adalah 16 orang.

1) Karakteristik umum subyek penelitian

Pada tabel 1 dibawah ini, menunjukkan bahwa total subyek penelitian adalah 16 orang $(n=30)$, dengan kelompok I dan kelompok II masingmasing berjumlah 8 orang (100\%), serta keseluruhan subyek berjenis kelamin perempuan $(100 \%)$.

Kemudian, pada tabel 2, karakteristik umur subyek kelompok I memiliki rerata 54.5 tahun, umur minimum 51 tahun, umur maksimum 67 tahun dan standar deviasi \pm 6.475 . Tinggi badan memiliki rerata $155 \mathrm{~cm}$, nilai minimum $150 \mathrm{~cm}$, nilai maksimum $158 \mathrm{~cm}$ dan standar deviasi 3.251 . Berat badan memiliki rerata $63.5 \mathrm{~kg}$, nilai minimum $50 \mathrm{~kg}$, nilai maksimum 
$75 \mathrm{~kg}$ dan standar deviasi \pm 7.171 . Sedangkan pada kelompok II, subyek memiliki rerata 63 tahun, nilai minimum 50 tahun, nilai maksimum 73 tahun dan standar deviasi \pm 7.978 . Tinggi badan memiliki rerata $153 \mathrm{~cm}$, nilai minimum $150 \mathrm{~cm}$, nilai maksimum $156 \mathrm{~cm}$ dan standar deviasi \pm 2.712 . Berat badan memiliki rata-rata $59 \mathrm{~kg}$, nilai minimum $48 \mathrm{~kg}$, nilai maksimum $57 \mathrm{~kg}$ dan standar deviasi \pm 6.761 .

Sedangkan, pada tabel 3 dibawah, dapat dilihat pada kelompok I persentasi IMT normal 12.5\%, overweight 25\%, obesitas I 50\% dan obesitas II $12.5 \%$ dengan rerata $25.85 \mathrm{~kg} / \mathrm{m}^{2}$. Sedangkan untuk kelompok II persentasi IMT normal 25\%, overweight 25\%, Obesitas $150 \%$ dan obesitas $20 \%$ dengan rerata $24.88 \mathrm{~kg} / \mathrm{m}^{2}$.

Tabel 1

Data Karakteristik Subyek Penelitian Berdasarkan Jenis Kelamin

Jenis kelamin subyek

\begin{tabular}{cccc} 
& Laki-laki & Perempuan & Persentase $(\%)$ \\
\hline Kelompok I & 0 & 8 & 100 \\
Kelompok II & 0 & 8 & 100 \\
Total & 0 & 16 & 100 \\
\hline
\end{tabular}

Tabel 2

Data Karakteristik Subyek Penelitian Berdasarkan Usia, Tinggi Badan dan Berat Badan

\begin{tabular}{|c|c|c|c|c|c|c|}
\hline Kelompok & $\mathrm{N}$ & Karakteristik & Minimum & Maksimum & Mean & $\begin{array}{l}\text { Standar } \\
\text { deviasi }\end{array}$ \\
\hline \multirow{3}{*}{ I } & \multirow{3}{*}{8} & Umur (tahun) & 51 & 67 & 54.50 & \pm 6.475 \\
\hline & & Tinggi badan $(\mathrm{cm})$ & 150 & 158 & 155 & \pm 3.251 \\
\hline & & Berat badan $(\mathrm{kg})$ & 50 & 75 & 63.50 & \pm 7.171 \\
\hline \multirow{3}{*}{$1 \mathrm{H}$} & \multirow{3}{*}{8} & Umur (tahun) & 50 & 73 & 63 & \pm 7.978 \\
\hline & & Tinggi badan $(\mathrm{cm})$ & 150 & 156 & 153 & \pm 2.712 \\
\hline & & Berat badan (kg) & 48 & 67 & 59 & \pm 6.761 \\
\hline
\end{tabular}

Tabel 3

Data Karakteristik Subyek Penelitian

Berdasarkan Indeks Massa Tubuh (Imt)

\begin{tabular}{ccccccc}
\hline \multirow{2}{*}{ Kelompok } & Normal & Overweight & Obesitas & Obesitas & \multirow{2}{*}{ Mean } \\
I & Jumlah & 1 & 2 & 4 & II & \\
& $\%$ & 12.5 & 25 & 50 & 12.5 & 25.85 \\
II & Jumlah & 2 & 2 & 4 & 0 & \multirow{2}{*}{24.88} \\
\hline
\end{tabular}

a. Karakteristik subyek penelitian berdasarkan distribusi frekuensi

1) Pekerjaan

Pada tabel 4 menunjukkan distribusi subyek pada masingmasing kelompok berdasarkan pekerjaan. Pada kelompok 1 sebanyak 7 orang dengan persentase $87.5 \%$ merupakan ibu rumah 
tangga dan sebanyak 1 orang dengan persentase $12.5 \%$ merupakan guru. Sedangkan pada kelompok II sebanyak 7 orang dengan persentase $87.5 \%$ merupakan ibu rumah tangga dan sebanyak 1 orang dengan persentase $12.5 \%$ merupakan pembantu rumah tangga.

Tabel 4

Distribusi Subyek Berdasarkan Pekerjaan

\begin{tabular}{ccccc}
\hline \multirow{2}{*}{ Pekerjaan } & \multicolumn{2}{c}{ Kelompok I } & \multicolumn{2}{c}{ Kelompok II } \\
& Frekuensi & Persentase & Frekuensi & Persentase \\
\hline Ibu rumah tangga & 7 & 87.5 & 7 & 87.5 \\
Pembantu rumah tangga & 0 & 0 & 1 & 12.5 \\
Guru & 1 & 12.5 & 0 & 0 \\
\hline
\end{tabular}

2) Umur

Pada tabel 5 distribusi subyek berdasarkan umur pada kelompok senam Yoga menunjukkan paling banyak pada rentang umur 50-53 tahun dan umur 54-57 tahun, yaitu sebanyak 3 orang, diikuti umur 62-65 tahun dan 66-69 tahun sebanyak orang 1 orang. Sedangkan pada kelompok senam Tai Chi paling banyak pada rentang umur 58-61 tahun dan umur 70-73, yaitu sebanyak 2 orang, diikuti umur 50-53, 54-57, 62-65 dan 66-69 tahun masing-masing sebanyak 1 orang.

\section{Tabel 5}

Distribusi Subyek Berdasarkan Umur

\begin{tabular}{ccccc}
\hline $\begin{array}{c}\text { Umur } \\
\text { (tahun) }\end{array}$ & \multicolumn{2}{c}{ Kelompok I } & \multicolumn{2}{c}{ Kelompok II } \\
\hline $50-53$ & 3 & 37.5 & 1 & 12.5 \\
$54-57$ & 3 & 37.5 & 1 & 12.5 \\
$58-61$ & 0 & 0 & 2 & 25 \\
$62-65$ & 1 & 12.5 & 1 & 12.5 \\
$66-69$ & 1 & 12.5 & 1 & 12.5 \\
$70-73$ & 0 & 0 & 2 & 25 \\
\hline
\end{tabular}

3) Indeks massa tubuh (IMT)

Pada tabel 6 dapat dilihat di kelompok I tidak ada subyek dengan klasifikasi kurus, normal sebanyak 1 orang dengan persentase $12.5 \%$, overweight sebanyak 2 orang dengan persentase $25 \%$, dan obesitas I sebanyak 4 orang dengan persentase $50 \%$ dan obesitas II sebanyak 1 orang dengan persentase $12.5 \%$. Sedangkan untuk kelompok II tidak ada subyek dengan klasifikasi kurus , klasifikasi normal sebanyak 2 orang dengan persentase $25 \%$, overweight sebanyak 2 orang dengan persentase $25 \%$, dan obesitas I sebanyak 4 orang dengan persentase $50 \%$. 
Tabel 6

Distribusi Subyek Berdasarkan Klasifikasi Indeks Massa Tubuh

\begin{tabular}{ccccc}
\hline \multirow{2}{*}{ IMT } & \multicolumn{2}{c}{ Kelompok I } & \multicolumn{2}{c}{ Kelompok II } \\
& Frekuensi & Persentase & Frekuensi & Persentase \\
\hline Kurus & 0 & 0 & 0 & 0 \\
Normal & 1 & 12.5 & 2 & 25 \\
Overweight & 2 & 25 & 2 & 25 \\
Obesitas I & 4 & 50 & 4 & 50 \\
Obesitas II & 1 & 12.5 & 0 & 0 \\
\hline
\end{tabular}

b. Keadaan Awal Subyek Penelitian

Seluruh subyek penelitian diukur nilai nyeri menggunakan kuesioner WOMAC Pain Scale. Hal ini menggambarkan kualitas nyeri lutut subyek sebelum mendapatkan perlakuan senam Yoga maupun senam Tai Chi. Data tersebut dicantumkan dalam tabel 7.

Berdasarkan hasil pengukuran pada tabel 7 , rerata nilai nyeri sebelum perlakuan pada kelompok I $(\mathrm{n}=8)$ adalah 15.5 dan standar deviasi \pm 1.604 . Hal ini menunjukkan nilai nyeri sebelum perlakuan pada kelompok I bervariasi dengan nilai minimum 13 dan nilai maksimum 18 . Sedangkan untuk kelompok II $(n=8)$, rata-rata nilai nyeri sebelum perlakuan adalah 15.63 dan standar deviasi \pm 1.302 . Hal ini menunjukkan nilai nyeri sebelum perlakuan pada kelompok II bervariasi dengan nilai minimum 13 dan nilai maksimum 17.

Tabel 7

Nilai Womac Pain Sebelum Perlakuan

\begin{tabular}{ccc}
\hline Penilaian & Kelompok I & Kelompok II \\
\hline $\mathrm{N}$ & 8 & 8 \\
Mean & 15.50 & 15.63 \\
Minimum & 13 & 13 \\
Maksimum & 18 & 17 \\
Standar Deviasi & \pm 1.604 & \pm 1.302 \\
\hline
\end{tabular}

\section{Data Deskriptif}

Pada hasil pengukuran nilai nyeri setelah perlakuan sebanyak 36 kali pada kelompok I $(\mathrm{n}=8)$, diperoleh nilai nyeri dengan rerata 5.38, standar deviasi \pm 2.504 , nilai minimum 2 dan nilai maksimum 10. Sedangkan pada kelompok II $(\mathrm{n}=8)$ diperoleh nilai nyeri dengan nilai rerata 3.88 , standar deviasi \pm 1.727 , nilai minimum 1 dan nilai maksimum 6. Hasil dapat dilihat pada tabel 8 .

Setelah diberi perlakuan, dilakukan pengambilan data post test. Hasil pengukuran menunjukkan bahwa keadaan subyek penelitian setelah mendapatkan perlakuan untuk kelompok I terdapat penurunan rata-rata nilai nyeri yaitu 10.12, sedangkan pada kelompok II terjadi penurunan rerata nilai nyeri sebesar 11.75. Hasil dapat dilihat pada tabel 9. Sedangkan pada tabel 10 menunjukkan nilai nyeri sebelum dan setelah perlakuan pada masing-masing 
subyek. Secara keseluruhan, setiap subyek mengalami penurunan nyeri setelah mendapatkan perlakuan dalam masing-masing kelompok.

Tabel 8

\begin{tabular}{ccc}
\multicolumn{3}{c}{ Nilai Womac Pain Setelah Perlakuan } \\
\hline Penilaian & Kelompok I & Kelompok II \\
\hline N & 8 & 8 \\
Mean & 5.38 & 3.88 \\
Minimum & 2 & 1 \\
Maksimum & 10 & 6 \\
Standar Deviasi & \pm 2.504 & \pm 1.727 \\
\hline
\end{tabular}

Tabel 9

Nilai Rata-Rata Womac Pain Sebelum Dan Setelah PerlakuAN

\begin{tabular}{ccccc}
\hline Kelompok & Penilaian & Sebelum & Setelah & $\begin{array}{c}\text { Perbedaan Sebelum } \\
\text { dan Setelah }\end{array}$ \\
\hline \multirow{4}{*}{ I } & N & 8 & 8 & 8 \\
& Mean & 15.50 & 5.38 & 10.12 \\
& Minimum & 13 & 2 & 11 \\
& Maksimum & 18 & 10 & 8 \\
& Standar Deviasi & \pm 1.604 & \pm 2.504 & \pm 0.9 \\
II & N & 8 & 8 & 8 \\
& Mean & 15.63 & 3.88 & 11.75 \\
& Minimum & 13 & 1 & 12 \\
& Maksimum & 17 & 6 & 11 \\
& Standar Deviasi & \pm 1.302 & \pm 1.727 & \pm 0.425 \\
\hline
\end{tabular}

Tabel 10

Nilai Rata-Rata Womac Pain Sebelum dan Setelah Perlakuan Masing-Masing Subyek

\begin{tabular}{|c|c|c|c|c|c|}
\hline & $\mathrm{N}$ & Nama Subyek & $\begin{array}{c}\text { Nilai } \\
\text { Nyeri } \\
\text { Pre Test }\end{array}$ & $\begin{array}{c}\text { Nilai } \\
\text { Nyeri } \\
\text { Post Test }\end{array}$ & $\begin{array}{c}\text { Perbedaan } \\
\text { Nilai Nyeri } \\
\text { Pre-Post Test }\end{array}$ \\
\hline \multirow{8}{*}{$\begin{array}{l}\text { Kelompok } \\
\text { I }\end{array}$} & \multirow{8}{*}{8} & Sugiyatni & 17 & 6 & 11 \\
\hline & & Sri Lestari & 14 & 6 & 8 \\
\hline & & Didik Sri & 15 & 3 & 12 \\
\hline & & Jumiati & 13 & 4 & 9 \\
\hline & & Sri Listya & 16 & 5 & 11 \\
\hline & & Retnaning & 15 & 2 & 13 \\
\hline & & TH Nurhastuti & 16 & 7 & 9 \\
\hline & & Purwanto & 18 & 10 & 8 \\
\hline \multirow{8}{*}{$\begin{array}{l}\text { Kelompok } \\
\text { II }\end{array}$} & \multirow{8}{*}{8} & THM Rukmini & 16 & 1 & 15 \\
\hline & & Yatmi & 15 & 6 & 9 \\
\hline & & Sikar & 17 & 5 & 12 \\
\hline & & Wagiyem & 17 & 4 & 13 \\
\hline & & Tugianti & 16 & 3 & 13 \\
\hline & & Sri Hartatik & 16 & 6 & 10 \\
\hline & & Suparni & 15 & 3 & 12 \\
\hline & & Suyati & 13 & 3 & 10 \\
\hline
\end{tabular}




\section{Analisis Data}

Analisis data penelitian menggunakan program SPSS 17, yang meliputi uji prasyarat analisis, uji homogenitas dan uji hipotesis.

a. Uji pra syarat analisis

Data penelitian diperoleh untuk mengetahui perbedan pengaruh senam Yoga dan senam Tai Chi terhadap penurunan nyeri OA lutut, pengaruh masing-masing perlakuan terhadap penurunan nyeri, serta perlakuan mana yang lebih efektif dalam menurunkan nyeri.

Uji normalitas

Data penelitian ini tidak dilakukan uji normalitas karena subyek penelitian kurang dari 30 orang, maka hipotesis penelitian ini diuji menggunakan uji statistik non parametrik (Hastono, 2001).

b. Uji homogenitas

Berdasarkan uji statistik pada data pre test antar kelompok menggunakan Mann-Whiney didapatkan hasil $\mathrm{p}=0.787$ ( $\mathrm{p}>0.05)$. Hasil ini menunjukkan tidak ada perbedaan nilai nyeri pada kelompok I dan kelompok II sebelum perlakuan. Maka, subyek pada kedua kelompok memiliki kondisi yang sama sebelum perlakuan.

c. Uji hipotesis

1) Uji hipotesis I

Berdasarkan hasil statistik uji beda hipotesis I menggunakan uji Wilcoxon untuk mengetahui pengaruh pemberian senam Yoga terhadap penurunan nyeri OA lutut, didapatkan hasil nilai $\mathrm{p}=0.011(\mathrm{p}<0.05)$. Hal ini menunjukkan bahwa ada pengaruh pemberian senam Yoga terhadap penurunan nyeri OA lutut.

2) Uji hipotesis II

Berdasarkan hasil statistik uji beda hipotesis II menggunakan uji Wilcoxon untuk mengetahui pengaruh pemberian senam Tai Chi terhadap penurunan nyeri OA lutut, didapatkan hasil nilai $\mathrm{p}=0.011(\mathrm{p}<0.05)$. Hal ini menunjukkan bahwa ada pengaruh pemberian senam Yoga terhadap penurunan nyeri OA lutut.

3) Uji hipotesis III

Berdasarkan hasil statistik uji beda hipotesis III menggunakan uji Mann-Whitney, dimana untuk mengetahui perbedaan pengaruh antara senam Yoga dan senam Tai Chi terhadap penurunan nyeri OA lutut yang dilihat dari nilai rata-rata post test nyeri dari masing-masing kelompok didapatkan hasil nilai $\mathrm{p}=0.220$ ( $\mathrm{p}>0.05)$. Hal ini menunjukkan bahwa tidak ada beda pengaruh yang signifikan pemberian senam Yoga terhadap penurunan nyeri OA lutut yang artinya senam Yoga maupun senam Tai Chi sama baiknya dalam menurunkan nyeri OA lutut. 


\section{B. Pembahasan}

Berdasarkan hasil uji Wilcoxon kelompok Yoga didapatkan hasil nilai $\mathrm{p}=$ 0.011 ( $\mathrm{p}<0.05$ ). Hal ini menunjukkan bahwa ada pengaruh signifikan pemberian senam Yoga terhadap penurunan nyeri OA lutut. Hal ini sesuai dengan hasil penelitian yang dilakukan oleh (Ebnezar et al., 2012) yang meneliti tentang Effectiveness of Yoga Therapy with the Therapeutic Exercises on Walking Pain, Tenderness, Early Morning Stiffness and Disability in Osteoarthritis of the Knee Joint A Comparative Study. Penelitian ini menggunakan subjek sebanyak 235 orang dengan usia 35-80 tahun, yang kemudian dibagi menjadi dua kelompok. Kelompok I merupakan kelompok senam Yoga sebanyak 118 orang dan kelompok kontrol sebanyak 117 orang. Kelompok Yoga diberikan senam Yoga selama 40 menit setiap hari selama 3 bulan, sedangkan kelompok kontrol mendapatkan therapeutic exercises dengan dosis yang sama. Hasil penelitian menunjukkan adanya perbedaan yang signifikan dalam pre dan post masing-masing kelompok (Wilcoxon, $\mathrm{p}<0.001$ ), juga ada perbedaan pengaruh yang signifikan antara kelompok Yoga dan kontrol (Man-Whitney, $\mathrm{p}<0.001$ ). Semua variable menunjukkan peningkatan yang lebih baik pada kelompok Yoga daripada kelompok kontrol ( $\mathrm{p}<0.001)$.

Pada penelitian (Ebnezar et al., 2012) dikatakan bahwa penurunan stamina otot dan spasme otot merupakan faktor lainnya yang memperberat nyeri dan disabilitas. Kedua hal ini dapat dikurangi dengan melakukan senam Yoga karena senam Yoga merupakan pendekatan holistik kesehatan yang meningkatkan fleksibilitas, kekuatan, dan stamina serta memperbaiki kesadaran diri dan wellness (Mehta, Mehta, \& Mehta, 1990). Selain itu, gerakan-gerakan senam Yoga cenderung rmenggunakan static stretching secara aktif yang akan berfungsi dalam koreksi postural dan memberikan efek traksi pada otot-otot di sekitar sendi sehingga terjadi peningkatan fleksibilitas (Middleton et al, 2013).

Senam Yoga memanfaatkan 3 fenomena terstimulasinya reseptor pada otot yaitu melalui muscle spindle, reciprocal inhibition dan golgi tendon organ (GTO). Saat stretching otot, terjadi perubahan panjang otot yang mengaktifkan muscle spindle di muscle belly yang akan mengirimkan sinyal perubahan panjang otot ke spinal cord yang akan menanggapi sinyal ini sebagai perubahan yang mengancam sehingga dia akan mengirimkan sinyal untuk kontraksi pada otot yang sedang diulur yang disebut stretch reflex. Maka, diperlukan penguluran yang dilakukan secara perlahan dan adanya penahanan yang pertahap agar muscle spindle beradaptasi terhadap perubahan sehingga spinal cord akan mengurangi kualitas impuls kontraksi sehingga otot lebih mudah diulur dan dapat lebih dalam lagi melakukan postur yoga yang kemudian akan meningkatkan fleksibilitas (Long \& Macivor, 2008).

Reciprocal inhibition menyeimbangkan kontraksi dan relaksasi otot secara bergantian antara agonis dan antagonis. Kontraksi otot antagonis dapat mengurangi aktivitas dari otot agonis melalui reciprocal inhibition. Impuls descending ke motorneuron pada otot antagonis, juga memberikan input eksitasi pada interneuron inhibisi Ia yang bersinaps pada motoneuron dari otot agonis. Hasil dari inhibisi 
motorneuron agonis dapat dibuktikan melalui meningkatkan input eksitasi dari aferen Ia antagonis diubah menjadi interneuron Ia yang sama, terutama selama kontraksi. Input aferen Ia dari antagonis biasanya terjadi dalam stretching sebagai kontributor terbesar terhadap elongasi agonis (Hunter \& Eckstein, 2009). Bebebapa penelitian memperlihatkan bahwa stretching berhubungan dengan pemendekan saat kontraksi antagonis untuk memanjangkan agonis mencapai ROM yang lebih luas dan efek ini dimanfaatkan saat melatih asana yoga (Long \& Macivor, 2008).

Kemudian saat senam Yoga, golgi tendon organ terstimulasi dengan adanya perubahan ketegangan otot yang terjadi selama menahan gerakan-gerakan (Long \& Macivor, 2008). GTO akan mengirimkan sinyal ke spinal cord tentang adanya perubahan ketegangan otot (Shah, 2012). Kontraksi otot yang terjadi saat menahan postur Yoga menimbulkan relaksasi otot setelah melakukan postur terebut yang akhirnya gerakan Yoga dapat meningkatkan fleksibilitas dan rileksasi tubuh (Long, 2008).

Hasil penelitian ini juga sejalan dengan penelitian (Kolasinski et al., 2005). berjudul Iyengar Yoga For Treating Symptoms Of Osteoarthritis Of The Knees: A Pilot Study pada subyek berusia lebih dari 50 tahun mengatakan bahwa Yoga yang meningkatkan kekuatan otot juga akan diikuti peningkatan kestabilan dan fleksibilitas sendi. Penelitian ini dilakukan selama 8 minggu dengan durasi 90 menit, seminggu sekali. Hasilnya, adanya perbaikan postur, peningkatan kesadaran terhadap posisi tubuh, peningkatan kekuatan otot yang dihasilkan dari yoga dapat menurunkan nilai nyeri WOMAC pain.

Nyeri sendiri merupakan gabungan dari proses faktor afektif, sikap dan kognitif. Pendekatan multi faktorial dari senam Yoga memberikan latihan yang tidak hanya melatih fisik melalui asana (postur yoga) tetapi meliputi juga pernapasan melalui pranayama, meditasi (dharana and dhyana), jnana yoga dan pengaturan emosi melalui bhakti yoga yang memicu gaya hidup yang lebih baik (Sindhu, 2006). Penguatan otot merupakan kunci dari latihan karena penyebab terbanyak dari nyeri dan disabilitas adalah karena kelemahan otot. Peningkatan fleksibilitas, mobilitas, koordinasi dan propioseptif dapat mengurangi nyeri.

Pada hasil uji Wilcoxon kelompok senam Tai Chi didapatkan nilai $\mathrm{p}=0.011$ $(\mathrm{p}<0.05)$. Hasil ini menunjukkan bahwa ada pengaruh signifikan pemberian senam Tai Chi terhadap penurunan nyeri OA lutut. Hal ini sesuai dengan penelitian yang dilakukan oleh (Chenchen Wang et al., 2009) berjudul Tai Chi is Effective in Treating Knee Osteoarthritis: A Randomized Controlled Trial. Penelitian ini dilakukan pada 40 orang dengan OA tibiofemoral yang secara acak dibagi menjadi 2 kelompok menjadi kelompok I Tai Chi dan kelompok II kontrol atensi. Kedua kelompok menjalani program selama 60 menit, 2 hari dalam seminggu selama 12 minggu. Nilai nyeri diukur menggunakan WOMAC index pain score pada minggu ke 12. Hasilnya, 20 subyek dengan rata-rata usia 65 tahun dan IMT $30 \mathrm{~kg} / \mathrm{m}^{2}$ yang mengiuti Tai Chi, mengalami penurunan nilai nyeri WOMAC pain dibandingkan dengan kelompok kontrol. 
Tai Chi dapat memberikan manfaat pada kardiovaskuler, meningkatkan kekuatan otot, keseimbangan, koordinasi dan fungsi fisik. Hal-hal tersebut diperkirakan dapat mengurangi nyeri sendi. Semakin kuat otot dan koordinasi yang lebih baik meningkatkan stabilitas sendi dan mengurangi nyeri karena kualitas nyeri berhubungan langsung dengan kelemahan otot (Chuan Ju Wang, Tsai, Liu, \& Chang, 2013).

Pada penelitian (Chenchen Wang et al., 2009) disimpulkan bahwa pada Tai Chi terjadi peningkatan kekuatan otot periatrikuler yang dapat menjaga sendi dari trauma. Keselarasan antara tubuh dan pikiran yang didapat dari Tai Chi dapat mempengaruhi sistem imun, endokrin, neurokimia dan fungsi otonom. Kemudian, latihan mengontrol pernapasan dan gerakan meningkatkan kondisi ketenangan mental dan fisik. Pengaruh ini dapat membantu memutus lingkaran nyeri. Peningkatan self-efficacy, fungsi sosial dan depresi dapat membantu untuk meningkatkan kepercayaan diri, dukungan dan memutus lingkaran nyeri.

Penurunan nyeri yang yang signifikan $(\mathrm{p}=0.000)$ terjadi setelah perlakuan selama 3 bulan pada Tai Chi di penelitian ini, juga sejalan dengan hasil penelitian dari Tsai et al (2013) berjudul A Pilot Cluster Randomized Trial of a 20-Week Tai Chi Program in Elders With Cognitive Impairment and Osteoarthritic Knee: Effects on Pain and Other Health Outcomes. Penelitian ini dilakukan pada subyek dengan usia yang lebih tua yaitu lebih dari atau sama dengan 60 tahun sebanyak 28 orang pada kelompok Tai Chi dan 27 orang pada kelompok kontrol selama 20 minggu. Pada minggu ke-8 sudah terdapat perbedaan yang signifikan terhadap penurunan nyeri yang terlihat lebih baik pada kelompok Tai Chi daripada kelompok kontrol dan penurunan nyeri ini terus terjadi sampai di minggu ke-20. Penelitian ini menyimpulkan, penurunan nyeri yang terjadi pada subyek yang lebih tua dapat terjadi lebih lambat dari subyek yang lebih muda tetapi penurunan yang terjadi dapat terjadi terus menerus sehingga diperkirakan bila subyek menjalani program Tai Chi dalam jangka panjang dapat lebih menurunkan nyeri OA lutut.

Kemudian, pembebanan yang adekuat dan tepat merupakan stimulus alami untuk mempertahankan homeostasis fisiologis sendi. Pembebanan saat melakukan Tai Chi dianggap cara yang ideal bagi penanganan OA karena gerakan Tai Chi cenderung low impact, memiliki pembebanan yang rendah pada sendi, melatih neuromuskuler dan memiliki pola gait yang perlahan dan spesifik (Torzilli et al., 1997). Menurut (Wu \& Hitt, 2005) beban paling berat pada sendi lutut ketika melakukan gerakan Tai Chi hanya setara 1.2 kali berat badan dan berat ini lebih kecil dibandingkan beban sendi lutut ketika berjalan yang terbebani 3 kali berat badan.

Berdasarkan hasil uji Mann-Whitney pada pada kelompok I dan II, didapatkan nilai $\mathrm{p}=0.220(\mathrm{p}>0.05)$. Hal ini menunjukkan tidak ada beda yang signifikan penurunan nyeri OA lutut antara kelompok senam Yoga dan senam Tai Chi yang artinya kedua perlakuan sama baiknya terhadap penurunan nyeri OA lutut. Secara teori, mekanisme biologis tentang proses Tai Chi mengurangi gejala pada OA lutut masih belum diketahui, tetapi keselarasan antara komponen fisik dan mental yang 
didapat dari senam Tai Chi tampak memberikan pengaruh utama dalam hal ini (Chenchen Wang et al., 2009).

Yoga dan Tai Chi memberikan efek relaksasi pada tubuh melalui kontrol pernapasan dan meditasi atau yang dalam istilah medis disebut biofeedback (Batra, 2011). Menurut (Rhoads, 2013) meditasi dapat mengalihkan kondisi narrow focus menjadi open focus. Kondisi narrow focus merupakan kondisi yang ada pada pasien dengan nyeri kronik dimana PHC gampang terstimulasi oleh sedikit impuls nyeri yang langsung menimbulkan reaksi ketegangan otot (attenstion state). Kondisi narrow focus ini dapat dilihat dari adanya gelombang beta pada gelombang otak. Bila gelombang beta muncul maka akan menstimulasi pengeluaran hormon stress seperti kortisol dan adrenalin, sebaliknya, kondisi open focus merupakan kondisi relaks pada tubuh dengan gambaran gelombang otak alfa dan gamma. Kedua gelombang ini menstimulasi pengeluaran neurotransmitter dopamin, serotonin, nor adrenalin, asetilkolin, GABA, dan endorphin. Neurotransmitter ini mengaktivasi saraf vagus yang menurunkan tekanan darah dan denyut nadi, menjadikan napas lebih dalam dan terkontrol (Fehmi \& Robbins, 2010).

Kemudian peningkatan endorphin saat senam Yoga bertanggung jawab atas berbagai reaksi fisiologis termasuk relaksasi dan well-being. Efek stretching saat Yoga memicu pengeluaran faktor neuroendokrin ini. Endorphin akan berikatan dengan reseptor di pemukaan jaringan yang menyebabkan membran sel membuka sehingga endorphin dapat masuk ke sel saraf untuk memberikan efek relaksasi sehingga nyeri berkurang (Long \& Macivor, 2008).

Endorphin mengontrol nyeri melalui stimulasi retikula formasio di batang otak yang mendepolarisasi neuron pertama sebelum terjadi sinapsis ke neuron kedua, menyebabkan neuron pertama dalam fase depolarisasi sehingga impuls ascendant yang muncul tidak ditransmisikan ke otak (Escudero, 2003).

Senam Yoga dan Tai Chi yang mengharuskan adanya pernapasan yang lebih dalam dan mengontrol gerakan yang dilakukan hingga tercapai gerakan yang stabil dan dalam kondisi tenang, secara tidak langsung melatih pergantian narrow focus menjadi open focus. Otot-otot yang relaks saat meditasi mengirimkan stimulus pada otak bahwa tidak ada potensi kerusakan jaringan atau bahaya lain. Hormon stress seperti kortisol dan adrenalin akan berkurang, tekanan darah dan denyut nadi pun akan menurun diikuti vasodilatasi pembuluh darah. Secara keseluruhan, kondisi ini menormalkan sistem dalam tubuh, (Rhoads, 2013).

Pada OA terjadi kerusakan artikular yang menstimulasi mekanoreseptor artikular untuk membangkitkan informasi sensoris yang abnormal dimana akan terjadi penurunan aktivasi volunter. Pada kerusakan artikular akan membangkitkan informasi aferen abnormal yang akan menurunkan eksitabilitas dari $\gamma$-motoneuron dan selanjutnya akan mengurangi aktivasi volunter otot-otot di sekitar lutut (Kidd, 2012).

Yoga dan Tai Chi sebagai senam dengan prinsip closed-kinetic chain (CKC) menstimulasi kembali propioseptor sendi lutut yang rusak karena OA. Mekanoreseptor pada sendi lutut akan terstimulasi melalui gerakan-gerakan 
tersebut yang akan meningkatkan eksitabilitas $\gamma$-motoneuron, ketajaman propioseptif dan peningkatan sensitivitas gelondong otot untuk berkontraksi sebagai stabilitas aktif sendi dalam gerakan sehingga kontak permukaan sendi lutut tidak menimbulkan nyeri saat lutut bergerak karena otot-otot periartikuler lutut menstabilkan gerakan (Clark, Röijezon, \& Treleaven, 2015).

Kedua senam ini meliputi gerakan-gerakan repetitif dan perlahan yang meningkatkan kontrol gerakan sendi pada berbagai posisi. Stabilitas dinamis sendiri dapat membantu mengontrol translasi sendi yang abnormal yang terjadi selama kegiatan sehari-hari dan meningkatkan kontrol motorik melalui alur reflek (Diracoglu, Aydin, Baskent, \& Celik, 2005).

Tai Chi dan Yoga dapat meningkatkan kekuatan otot, keseimbangan, koordinasi dan fungsi fisik. Hal-hal tersebut diperkirakan dapat mengurangi nyeri sendi. Semakin kuat otot dan koordinasi yang lebih baik meningkatkan stabilitas sendi dan mengurangi nyeri karena kualitas nyeri berhubungan langsung dengan kelemahan otot (Tsai, Egelman, Cranor, \& Acquisti, 2011).

\section{Kesimpulan}

Berdasarkan hasil penelitian yang dilakukan selama 3 bulan yaitu mulai tanggal 1 Januari 2015 sampai 30 Maret 2015 di Sanggar senam RM 7 Malangjiwan RT 09/02 Colomadu, Surakarta, Jawa Tengah tentang perbedaan pengaruh senam Yoga dan senam Tai Chi terhadap penurunan nyeri osteoartritis lutut sebanyak 36 kali perlakuan, didapatkan kesimpulan sebagai berikut: (1) ada pengaruh yang signifikan senam Yoga terhadap penurunan nyeri OA lutut, (2) ada pengaruh yang signifikan senam Tai Chi terhadap penurunan nyeri OA lutut, (3) tidak ada perbedaan pengaruh yang signifikan antara senam Yoga dan senam Tai Chi terhadap penurunan nyeri OA lutut dan (4) senam Yoga dan senam Tai Chi sama baiknya dalam menurunkan nyeri pada OA lutut. 


\section{BIBLIOGRAFI}

Batra, Abhinandan. (2011). Comparative Study of the Effects of Tai Chi and Strength Training on Osteoarthritis in Older Adults.

Bennell, Kim L., \& Hinman, Rana S. (2011). A review of the clinical evidence for exercise in osteoarthritis of the hip and knee. Journal of Science and Medicine in Sport, 14(1), 4-9.

Chen, Wei Wen, \& Wong, Yi Lee. (2015). Chinese mindset: Theories of intelligence, goal orientation and academic achievement in Hong Kong students. Educational Psychology, 35(6), 714-725.

Clark, Nicholas C., Röijezon, Ulrik, \& Treleaven, Julia. (2015). Proprioception in musculoskeletal rehabilitation. Part 2: Clinical assessment and intervention. Manual Therapy, 20(3), 378-387.

Ebnezar, John, Nagarathna, Raghuram, Yogitha, Bali, \& Nagendra, Hongasandra Ramarao. (2012). Effects of an integrated approach of hatha yoga therapy on functional disability, pain, and flexibility in osteoarthritis of the knee joint: a randomized controlled study. The Journal of Alternative and Complementary Medicine, 18(5), 463-472.

Fehmi, Les, \& Robbins, Jim. (2010). Dissolving pain: Simple brain-training exercises for overcoming chronic pain. Shambhala Publications.

Ghasemi, Gholam A., Golkar, Ainaz, \& Marandi, Sayyd M. (2013). Effects of hata yoga on knee osteoarthritis. International Journal of Preventive Medicine, 4(Suppl 1), S133.

Hawker, Gillian A., Mian, Samra, Kendzerska, Tetyana, \& French, Melissa. (2011). Measures of adult pain: Visual analog scale for pain (vas pain), numeric rating scale for pain (nrs pain), mcgill pain questionnaire (mpq), short-form mcgill pain questionnaire (sf-mpq), chronic pain grade scale (cpgs), short form-36 bodily pain scale (sf-36 bps), and measure of intermittent and constant osteoarthritis pain (icoap). Arthritis Care \& Research, 63(S11), S240-S252.

Kidd, Bruce. (2012). Mechanisms of pain in osteoarthritis. HSS Journal, 8(1), 26-28.

Komalasari, Tresna, Permatasari, Tria Astika Endah, \& Supriyatna, Nana. (2020). Pengaruh Edukasi Dengan Metode Peer Group Terhadap Perubahan Pengetahuan, Sikap dan Tekanan Darah Pada Lansia Di UPTD Puskesmas Sukahaji Kabupaten Majalengka. Syntax Literate; Jurnal Ilmiah Indonesia, 5(5), 184-196.

Rhoads, C. J. (2013). Mechanism of pain relief through Tai Chi and Qigong. J Pain Relief, 2(115), 846-2167.

Shah, Salvi. (2012). Plyometric exercises. International Journal of Health Sciences and Research, 2(1), 115-126. 
Susko, Allyn M., \& Fitzgerald, G. Kelley. (2013). The pain-relieving qualities of exercise in knee osteoarthritis. Open Access Rheumatology: Research and Reviews, 5,81 .

Tsai, Janice Y., Egelman, Serge, Cranor, Lorrie, \& Acquisti, Alessandro. (2011). The effect of online privacy information on purchasing behavior: An experimental study. Information Systems Research, 22(2), 254-268.

Wang, Chuan Ju, Tsai, Ming Feng, Liu, Tse, \& Chang, Chin Ting. (2013). Financial sentiment analysis for risk prediction. Proceedings of the Sixth International Joint Conference on Natural Language Processing, 802-808. 